\title{
Climate influences ON GROWTH AND reproduction of Pinus banksiana (Pinaceae) at THE LIMIT OF THE SPECIES DISTRIBUTION IN EASTERN NORTh AMERICA ${ }^{1}$
}

\author{
EMma Despland AND Gilles Houle²
}

\author{
Département de biologie and Centre d'études nordiques, Université Laval, Sainte-Foy, Québec, Canada G1K 7P4
}

\begin{abstract}
The presence of conflicts in the allocation of resources among the different functions of an organism is a fundamental postulate of modern ecology. It is assumed that reproduction occurs at a cost because it monopolizes resources that could be used for other functions (e.g., growth). These conflicts may be particularly evident under stressful conditions, such as under low water or nutrient availability, or under severe climatic conditions. There we may expect to find strong negative relationships between an organism's growth and reproduction. We studied a population of Pinus banksiana (Pinaceae) at the northern limit of the species distribution, in subarctic Québec (Canada) where Pinus banksiana occupies nutrient-poor, sandy terraces along the Great Whale river. Serotinous cones of Pinus banksiana produced between 1969 and 1992 were sampled to estimate interannual variations in several variables representing reproduction, and to relate these to climate and tree growth. Climate appears to influence each developmental stage involved in the production of viable seeds, from the time of cone initiation to that of seed maturation. In general, reproductive variables are positively related to high temperatures during the three growing seasons required for seed production; growth is also positively correlated to summer temperatures. Consequently, investment in maturing seeds is positively associated with growth. Thus, both reproduction and growth covary with climate: during relatively warm and long growing seasons, resource allocation to both functions increases. Under these conditions, no trade-off is apparent.
\end{abstract}

Key words: climate; cost of reproduction; dendrochronology; partial Mantel test; Pinaceae; Pinus banksiana; seed production; subarctic Québec; trade-off.

Reproduction often constitutes an important resource investment for plants, even for trees. For example, estimates of reproductive effort in Pinus spp. vary between 10 and $18 \%$ of stem annual biomass or between 2 and $6 \%$ of total annual photosynthesis (Ovington, 1961; Linder and Troeng, 1981). Moreover, reproductive structures generally contain high concentrations of mineral nutrients (Ovington, 1963; Rohmeder, 1967; West and Lott, 1993): for example, reproductive effort in Pinus sylvestris constitutes $10-15 \%$ of the biomass, but $40-50 \%$ of the nutrients invested in stem increment (Cannell, 1985). Because the resources available to an organism are ultimately finite, increased investment in reproduction may entail decreased allocation elsewhere (i.e., a trade-off), for example, in growth (Cody, 1966; Gadgil and Bossert, 1970; Stearns, 1976, 1989). Therefore, we may expect reproduction and growth to be negatively related to one another through time in long-lived organisms.

Years of high reproductive output have been shown for both woody gymnosperms and angiosperms to coincide with years of low radial growth (Morris, 1951; Gross, 1972; Linhart and Mitton, 1985); this is consistent with

\footnotetext{
${ }^{1}$ Manuscript received 9 May 1996; revision accepted 6 January 1997.

The authors thank L. Lapointe and L. Filion for insight, discussion, and criticism, and P. Babeux, R. Pilote, S. Boudreau, M. Bergeron, and O. Couture for work in the field and in the laboratory. For their comments on an earlier version of the manuscript, we thank D. Inouye and two anonymous reviewers. This research was financially supported by the Natural Sciences and Engineering Research Council of Canada through a graduate scholarship to E. Despland and a research grant to G. Houle. Financial support was also provided by Indian and Northern Affairs Canada.

${ }^{2}$ Author for correspondence.
}

the existence of a trade-off in resource allocation. However, this type of relationship is by no means universal: null (e.g., Eklund, 1954; Daubenmire, 1960; Willson, 1986; Dick, 1991) as well as positive (e.g., Nienstaedt, 1985; Oyama, 1990; Cremer, 1992) relationships between reproduction and growth have also been reported. Increased reproductive output could be associated with increased growth if, for example, both functions are dependent upon similar favorable climatic conditions (Nienstaedt, 1985). A lack of significant relationship between reproduction and growth could simply point out the significance of other factors (e.g., predators on reproductive structures and/or on foliage) in controlling one or both processes.

The quality and quantity of seeds produced by trees often vary considerably between years. Masting, i.e., events of massive reproduction separated by periods of no or low reproduction, has been related to carbon pool exhaustion and subsequent replenishment within the individual (Silvertown, 1980; Kelly, 1994). Masting may negatively affect the growth of an organism for several years, thereby creating significant temporal variations in growth (Gysel, 1971). But factors other than internal ones may cause temporal variability in both reproduction and growth. For example, Houle and Filion (1993) have documented significant interannual variations in the reproductive output of jack pine (Pinus banksiana Lamb.) at the northern limit of its distribution in Québec (Canada), and have linked them to climate conditions at different periods during cone development. Likewise, tree radial growth strongly responds to local temperature and precipitation; in fact, past climates have often been recon- 
structed from tree ring chronologies (e.g., Cook and Jacoby, 1977; Briffa et al., 1990). While temporal variations of tree reproduction and growth can be related to a number of different factors, climate appears to be the most important one over wide geographical areas (Lee, 1979).

In the present paper, we examine the influence of climate on the different steps involved in seed production, and evaluate the relationship between growth and reproduction for a Pinus banksiana (Pinaceae) population in subarctic Québec (Canada). The study was conducted at the northern limit of the species' range on a nutrient-poor, sandy substrate, as it has been hypothesized that the effect of climate on reproduction and growth would be greater, and resource allocation conflicts more significant under stressful conditions. This study comprises two parts: in the first section, we evaluate the interannual variations in growth and reproduction within a population, and relate them to each other and to regional climate. In the second section, as a preliminary analysis, we examine in detail the patterns of growth and reproduction within a single tree to determine the spatiotemporal variations of reproductive output within the crown, and to relate growth and reproduction within small sections of the tree.

The species-The geographic distribution of Pinus banksiana more or less corresponds to that of the boreal forest in North America (Rousseau, 1974). P. banksiana is a pioneer tree species, has a relatively short longevity and a high growth rate, and is well adapted to regenerate after fire (Rudolph and Laidly, 1990). In the northern part of the species' range in Québec, maintenance of populations of the species is dependent upon a specific fire regime, with a recurrence time shorter than $\sim 100 \mathrm{yr}$ (Desponts and Payette, 1992).

$P$. banksiana produces resinous, heavily lignified, serotinous cones, which open only at high temperatures. In the absence of fire, these cones may remain closed on the trees for decades (Schantz-Hansen, 1941; Rudolph and Laidly, 1990). Because the exact age of the cones can be determined, the annual female reproductive effort of a given tree can be estimated and correlated with its own radial growth and with climate over many years.

Cone development in pines takes place over a period of three calendar years: the reproductive buds are initiated in the fall and overwinter inside the vegetative buds. Male and female strobili appear the following spring, and then pollination occurs. The pollen tube germinates on the nucellus and grows toward the ovule throughout the summer. Fertilization occurs in the following spring, after which the embryo develops rapidly and matures within the same season (Singh, 1978). Three growing seasons are thus involved in the development of a single cohort of cones; in this paper, they will be referred to as the seasons of cone initiation, pollination, and seed maturation. Climate during these three years affects the different steps that ultimately lead to the production of the seeds (Houle and Filion, 1993).

\section{METHODS}

Study area-The northernmost jack pine stands in Québec occupy well-drained sandy terraces in the valley of the Great Whale river and were inventoried by Desponts (1990). The stand we studied in 1994 $\left(55^{\circ} 02^{\prime} 05^{\prime \prime} \mathrm{N}, 75^{\circ} 42^{\prime} 47^{\prime \prime} \mathrm{W}\right)$ regenerated after a crown fire that occurred in 1921. It is composed of an even-aged, $\sim 70$-yr old jack pine population (804 stems/ha), interspersed with younger black spruces [Picea mariana (Mill.) BSP; 201 stems/ha] and a few tamaracks [Larix laricina (Du Roi) K. Koch; 8 stems/ha]. Mean height and diameter at the base for jack pine trees are $8.2 \mathrm{~m}$ and $15.2 \mathrm{~cm}$, respectively. The understory is very sparse and a lichen (Cladina mitis (Sandst.) Hustich) ground cover predominates. Desponts (1990) has calculated a fire recurrence interval of $53 \mathrm{yr}$ for the last 200-yr period in the Great Whale river valley.

Mean annual temperature in the region is $-4^{\circ} \mathrm{C}$ and mean annual precipitation totals $700 \mathrm{~mm}$ of which $40 \%$ falls as snow (Wilson, 1971). The nearest weather station with a complete record for the period under study is located in Whapmagoostui-Kuujjuaraapik (Great Whale meteorological station, $55^{\circ} 17^{\prime} \mathrm{N}, 77^{\circ} 46^{\prime} \mathrm{W}, 18 \mathrm{~m}$ above sea level), on the east coast of Hudson Bay, $120 \mathrm{~km}$ west of the study site. Comparisons of these weather data with those from the station at Bienville lake (150 $\mathrm{km}$ east of the study site) for the period during which the latter are available, show that interannual temperature variations are well correlated throughout the region; precipitation, however, varies more locally (Despland, 1995). Unfortunately, there is no weather station closer than the Great Whale station that has a sufficiently long recording interval for the analyses we conducted. In this paper, we calculated Spearman's rank correlation coefficients between mean summer (June-August) temperature and total summer (June-August) precipitation, and jack pine growth and reproduction.

Sampling methods-Fifteen dominant pines were selected for the study (healthy appearance, regular crown, no obvious damage from ice storm, and bearing abundant cones). The trunk of each individual was divided into 1-m segments, and each segment was divided into north, south, east, and west quadrants. A single reproductive branch was randomly selected from each quadrant and brought back to the laboratory. This selective sampling ensured an equal representation of all parts of the tree crown and permitted an analysis of the variations of reproductive effort within a tree. The trees were then felled, and cross sections were collected at the base and at every metre along the trunk for stem analysis.

Dendrochronology - The stem cross sections were sanded with a fine grade of sand paper and age was determined by counting growth rings. Annual ring width was measured on two opposite radii using a Henson micrometer (precision of $0.01 \mathrm{~mm}$ ).

For the first part of the study, a growth ring chronology was established using the basal disks from the 15 trees sampled. The period from 1969 to 1992 from each individual was indexed using first- or secondorder polynomials according to the shape of the growth curve, to remove long-term trends. An average chronology was then calculated and correlated to reproductive effort. No long-term tendency was present in the reproductive variable chronologies (see Results); consequently, we used the raw values of these variables for the correlations. The relationship between radial growth and climate was evaluated for the period 1932-1988: we calculated 15-yr moving averages for each chronology, divided the raw data by the $15-\mathrm{yr}$ moving average curve in order to eliminate low frequency variations associated with tree age, and then pooled the resulting curves to obtain a filtered chronology (56 yr).

For the second part of the study, we retained for stem analysis the raw data series 1969-1992 from the trunk cross sections of a single individual (292) corresponding to levels in the crown where cones were present. Local growth (terminal shoot elongation from 1984 to 1993 and branch radial increment) was also evaluated on tree 292 and compared with the reproductive effort of the same branches. Tree 292 was selected because it was the most representative of those sampled, both in its reproduction and in its radial growth (i.e., highest correlations with the 15 tree chronologies). 
Reproductive effort-On the branches sampled, all cones $<25 \mathrm{yr}$ of age were precisely dated, either by counting terminal bud scars from the branch apex, or by counting growth rings on a branch cross section at the base of the cone. One cone per year per branch was randomly selected, and placed in a paper bag in an oven at $72^{\circ} \mathrm{C}$ for $4 \mathrm{~h}$ (Young and Young, 1992). After the cones opened, we counted the number of fertile scales and formed seeds per cone.

Seed mass and viability were estimated on two different subsamples: for the first part of the study, we used the cones from the branch collected in the southern quadrant, between 1 and $2 \mathrm{~m}$ from the stem apex of each tree. For the second part of the study, all the cones from tree 292 were retained.

From each of these cones, a subsample of 20 seeds was randomly chosen and weighed individually. In order to determine seed viability, 25 seeds per cone were randomly selected and placed in a germination cabinet (14-h photoperiod, $30^{\circ} \mathrm{C}$ day and $20^{\circ} \mathrm{C}$ night; Young and Young, 1992) in Petri dishes on filter paper soaked with a fungicide solution (Captan-Benomyl, $0.25 \mathrm{~g} / \mathrm{kg}$ ). Germinated seeds were counted and removed daily for a period of $28 \mathrm{~d}$. Germination velocity was calculated according to the following equation:

Germination velocity $=\left[\Sigma\left(G_{d} / d\right) / G_{t}\right] \times 100$,

where $G_{d}$ represents the number of seeds germinating on day " $d$ ", $d$ is the number of days since the beginning of the test, and $G_{t}$ is the total number of germinated seeds at the end of the test (Mugnisjah and Nakamura, 1986). We dissected nongerminated seeds, and those containing an embryo were placed in tetrazolium chloride (1\% aqueous solution) for $24-48 \mathrm{~h}$ to assess their viability. Total viability estimates include germination and staining trials.

Statistical analyses-For the first part of the study, we used Spearman's rank correlation analyses to determine the relationships between the different reproductive variables, as well as between these variables and radial growth and climate. Several variables were used to estimate reproductive effort: number of cones per cone-bearing branch; number of fertile scales per cone (each scale supports two ovules); percentage formed seeds, i.e., [formed seeds $/(2 \times$ fertile scales $)$ ] $\times 100$, this variable representing the percentage of ovules that began their development; percentage filled seeds, i.e., (filled seeds/formed seeds) $\times 100$, this variable representing the percentage of seeds containing an embryo; percentage viable embryos, i.e., (viable seeds/filled seeds); germination velocity; and seed mass.

These variables were correlated with radial growth, as well as with summer temperature and precipitation with a lag of $0,+1$, and $-1 \mathrm{yr}$ in order to include the three growth seasons involved in cone development. We also correlated radial growth of the year following seed maturation $\left(\right.$ year $_{+2}$ ) with the various reproductive variables, because negative effects of reproduction on growth could also be manifested subsequent to the year of seed maturation. Ring width was correlated with summer temperature and precipitation during the year of ring formation, and with those of the previous year.

Repeated-measures analyses of variance (ANOVAs) were performed on the reproductive variables (after appropriate transformation) to determine the significance of interannual fluctuations. In these analyses, each one of the 15 trees sampled is a "subject" on which measures on a given variable (e.g., number of fertile scales per cone) are taken through time. Kendall concordance tests (Sokal and Rohlf, 1981) were used to determine the degree of synchronism among the 15 individuals sampled, both in terms of cone crop and number of seeds per cone. A Kendall concordance test is the equivalent of a nonparametric correlation test among more than two variables, in the present case, among the 15 chronologies (one for each jack pine tree sampled) of cone crop or seed number per cone.

For the second part of the study, the growth and reproduction data from tree 292 were represented as stem analyses: this common dendrochronological technique shows annual growth increment (and in this case, annual reproductive effort as well) in relation to vertical position along the trunk. In order to minimize the number of statistical tests, reproductive effort was represented by three integrating variables: number of cones per cone-bearing branch, mass of seeds per cone (seeds per cone $\times$ mean seed mass), and total mass of seeds per branch. These variables were correlated to radial growth increment during the $3 \mathrm{yr}$ involved in cone development by means of partial Mantel tests (Legendre and Vaudor, 1991). A partial Mantel test is similar to a Pearson partial correlation, but it accounts for autocorrelation by computing residual matrices of the linear regression of two variables (e.g., growth and reproduction) over the values of a third one (e.g., $x$ and $y$ coordinates). A partial Mantel test is, in fact, a partial correlation between distance matrices (Legendre and Fortin, 1989; Brodie, Houle, and Fortin, 1995). In this study, autocorrelation is considered in a plane including one spatial dimension ( $y$ : height in the tree) and one time dimension ( $x$ : year of ring formation or of pollination for the reproductive variables)

The relationship between reproduction and local growth was evaluated on two branches from tree 292 with continuous cone production over the study period. We used Spearman's coefficients of rank correlation to compare reproductive effort of these branches with branch radial increment and terminal shoot elongation.

\section{RESULTS}

Population level-We found significant interannual and interindividual differences for each of the reproductive variables analyzed (repeated-measures ANOVAs: all $P$ s $<0.0001)$. However, the Kendall concordance tests indicated a significant synchronism among the individuals studied, in terms of cone crop $\left(W=0.43 ; \chi^{2}=90\right.$; $P<0.01)$ and number of seeds per cone $\left(W=0.49 ; \chi^{2}\right.$ $=103 ; P<0.01)$.

Figure 1 shows the interannual fluctuations of the seven reproductive variables studied, as well as radial growth. Neither seed viability nor germination velocity diminish with cone age, contrary to what the literature suggests (e.g., Roe, 1963; Popovich, Demers, and Gagnon, 1970; Rudolph and Laidly, 1990). Several reproductive variables are positively correlated (Table 1). For example, number of fertile scales, seed viability, and germination velocity are positively correlated with cone number; seed mass, germination velocity, and proportion of filled and viable seeds are all positively correlated. The relationship between seed mass and percentage filled seeds is not surprising, because filled seeds weigh more than empty ones. There does not appear to be a significant negative relationship between seed number and their mass or viability.

The development of an ovule into a viable seed involves several steps that are represented by the different reproductive variables we analyzed (Fig. 2). The number of viable seeds that are produced in a given year depends on the survival rate at each developmental stage during the 3-yr reproductive process. Indeed, different reproductive variables are significantly correlated with climate at different periods during cone development (Table 2): scale number and percentage of filled and viable seeds are positively related to temperature during the season of cone initiation (only marginally significant coefficients for percentage of filled and viable seeds vs. temperature). Seed mass and percentage filled seeds increase with temperature during the pollination season. A positive relationship also exists between temperature during the seed 

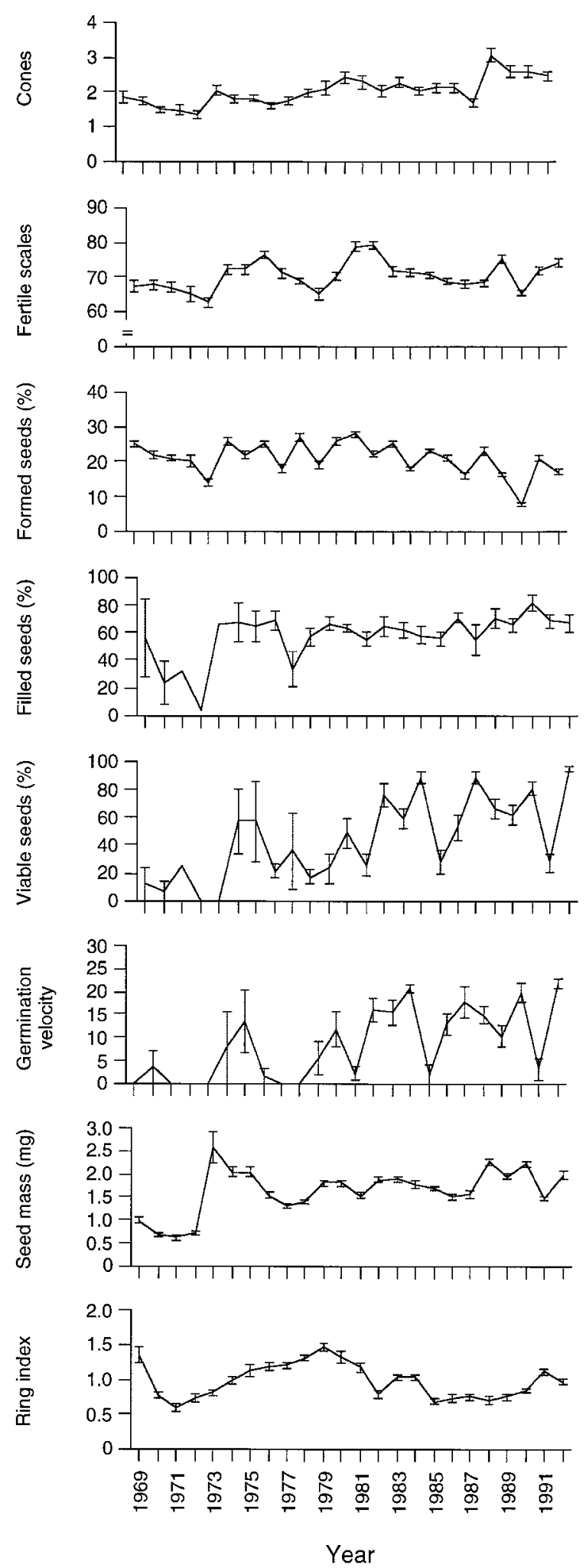

Fig. 1. Interannual fluctuations in the number of cones per reproductive branch, number of fertile scales per cone, percentage formed seeds, percentage filled seeds, percentage viable seeds, germination velocity, seed mass, and ring index for a population of Pinus banksiana at the northern limit of the species' distribution in Québec. Means \pm 1 SE presented. maturation season and seed mass and germination velocity.

Radial growth is positively correlated with summer temperature during ring formation (Spearman's coefficient of rank correlation: $r_{s}=0.33, P=0.03$ ). However, ring width is not significantly related to precipitation of the current year or to either temperature or precipitation during the year preceding ring formation (all $P \mathrm{~s}>0.05$ ).

Although reproduction and growth are similarly influenced by climate, we observed only one significant relationship (a positive one) between these two functions (Table 2). However, these analyses are based on averages encompassing several trees and different positions in each tree, and thus include variation due to factors beyond the scope of the first part of this study (e.g., branch vigor and position). Next, we will explore the relationships between reproduction and growth within a single tree and eliminate some of the variation just mentioned.

Individual level - Visual observation of the spatial distribution of reproductive effort within the tree crown does not reveal any obvious relationship between the reproductive variables and height of the branch in the tree. However, all reproductive variables exhibit higher values in the southern quadrant (Despland, personal observation). The stem analyses representing reproductive effort do not show any clear spatial pattern of variation, but display the same interannual fluctuations that we observed at the population level (Figs. 1, 3).

The partial Mantel tests reveal only nonsignificant relationships between the three reproductive variables and radial growth during the seasons of cone initiation and of pollination (Table 3). However, a significant positive correlation exists between stem increment in the season of maturation and seed mass per cone. The same relationships are observed at the local level: on one of the two branches studied, seed mass per cone and total seed mass per branch are positively correlated to branch radial increment and terminal shoot elongation during the season of seed maturation (Table 4).

\section{DISCUSSION}

Cone initiation-Our results suggest that high temperatures during the season of cone initiation favor high reproductive effort in jack pine; this is mainly expressed as an increase in the number of fertile scales, though the number of cones also increases concurrently. In jack pine, male cones are initiated during the summer, but female cones differentiate at the end of the growing season (Moore and Nozzolillo, 1991); a slightly longer growing season might thus have a great impact on female cone initiation in the subarctic. Cone bud initiation of different conifer species in a variety of environments has been correlated with high temperatures (Maguire, 1956; Daubenmire, 1960; Lester, 1967; van Vredenburch and la Bastide, 1969; Kleinschmidt, Schmidt, and Hosenfeld, 1980; Simpson and Powell, 1981), low precipitation (Ebell, 1967; Rehfeld, Stage, and Bingham, 1971; Shoulders, 1973), and water stress associated with the combination of the two above factors (Yanagihara, Tochiaki, and Arai, 1960; Fraser, 1962; Caron and Powell, 1989b; Woodward et al., 1994). We also found a negative, though not sig- 
TABLE 1. Spearman's coefficients of rank correlation ( $r_{s}$ and associated $P$ value) between different reproductive variables for Pinus banksiana at the northern limit of its distribution in Québec. ${ }^{\mathrm{a}}$

\begin{tabular}{|c|c|c|c|c|c|c|}
\hline & $\begin{array}{l}\text { Fertile } \\
\text { scales }\end{array}$ & $\begin{array}{c}\text { Formed } \\
\text { seeds }\end{array}$ & $\begin{array}{l}\text { Filled } \\
\text { seeds }\end{array}$ & $\begin{array}{l}\text { Viable } \\
\text { seeds }\end{array}$ & $\begin{array}{c}\text { Germination } \\
\text { velocity }\end{array}$ & $\begin{array}{l}\begin{array}{l}\text { Seed } \\
\text { mass }\end{array} \\
\end{array}$ \\
\hline Formed seeds & & & -0.12 & -0.29 & -0.27 & -0.20 \\
\hline Filled seeds & & & & $\begin{array}{c}0.35 \\
(0.09)\end{array}$ & $\begin{array}{c}0.41 \\
(0.05)\end{array}$ & $\begin{array}{c}0.65 \\
(\mathbf{0 . 0 0 2})\end{array}$ \\
\hline Germination velocity & & & & & & $\begin{array}{c}0.58 \\
(0.006)\end{array}$ \\
\hline
\end{tabular}

${ }^{a} P$ values, in parentheses, shown only for correlations significant at $P \leq 0.1$; correlations significant at $P<0.05$ shown in boldface.

nificant, relationship between precipitation and cone initiation.

The proportions of filled and of viable seeds appear to be related to weather conditions during the season of cone initiation, as well as to number of cones and fertile scales. Proportion of filled seeds has been shown to be positively correlated with the number of scales per cone in Picea mariana (Caron and Powell, 1989a). Male and female cone production are generally synchronized; rate of pollination and thus number of filled seeds increase in years of high cone production (Hyde, 1963; Caron and Powell, 1989b).

Pollination-Pine embryo development has mostly been studied in vitro, and the reasons why so few ovules develop into viable seeds under natural conditions are largely unknown. Prezygotic ovule abortion occurs mainly during the summer immediately following pollination and leads to the formation of an empty seed (Owens, Simpson, and Molder, 1981). Ovule abortion has been

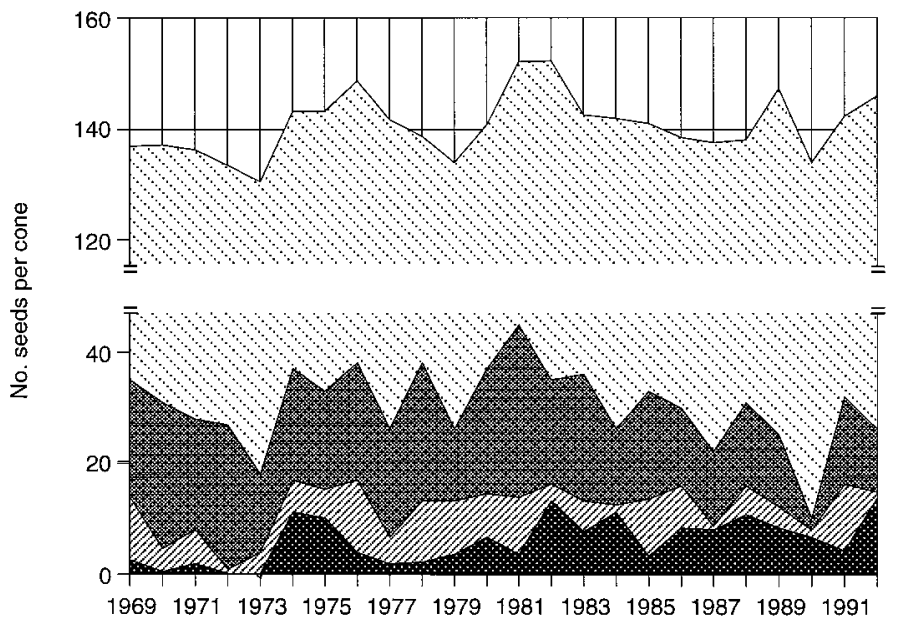

Year of cone appearance (i.e., pollination year)

$\because$ Potential seeds Formed seeds Filled seeds

Viable seeds

Fig. 2. Interannual variations in the number of seeds per cone at each developmental stage for a population of Pinus banksiana at the northern limit of the species' distribution in Québec. Data presented cumulatively. linked to different factors, including competition between ovules or with vegetative meristems, low pollination rates, or low pollen vigor and viability (Owens and Blake, 1986). When the pollination tube germinates on the nucellus, it begins to grow toward the megaspore and stimulates gametophyte development. The communication mechanism is still poorly understood, but the presence of viable, vigorous pollen is necessary to prevent ovule mortality; moreover, the nucellus rejects conspecific and interspecific noncompatible pollen (Owens and Blake, 1986).

In our study, the proportion of filled seeds was correlated with high temperatures during the pollination season. In general, high temperatures both during and following pollination seem to play an important role in promoting conifer reproductive success (Maguire, 1956; Lowry, 1966; van Vredenburch and la Bastide, 1969). Low temperatures during pollination can cause ovule abortion (Maguire, 1956; Owens and Molder, 1979; Owens, Colangeli, and Morris, 1991) and diminish pollen vigor and viability (Owens, 1991).

Seed maturation-In spring of the year following pollination, the pine gametophyte completes its development, archegonia form, and fertilization occurs, after which the gametophyte and embryo grow rapidly, drawing on the reserves in the nucellus (Singh, 1978; Owens, Simpson, and Molder, 1982). Proembryo abortion leads to the formation of an empty seed, while mortality of well-developed embryos gives rise to a filled, nonviable seed (Owens, 1991). Postzygotic mortality can be due to several factors. Proembryo abortion is generally linked to self fertilization and the expression of lethal genes, and is poorly related to external factors (Owens, 1991). Mortality later in embryological development is generally associated with unfavorable environmental conditions (Owens and Blake, 1986). Indeed, in our study seed viability is correlated with high temperatures during the season of seed maturation.

During the summer of maturation, the cones grow considerably and thus constitute important sinks. In Pinus contorta, second-year cones represent $17-45 \%$ of the dry mass of the annual shoot (Dick, Leaky, and Jarvis, 1990). Seed mass also increases significantly following fertilization (Singh, 1978), as lipids (Johnson et al., 1987; Tautorus, Fowke, and Dunstan, 1991), protein (Donokaya, 
TABLE 2. Spearman's coefficient of rank correlation ( $r_{s}$ and associated $P$ value) between different reproductive variables and radial growth and climate for Pinus banksiana at the northern limit of its distribution in Québec. ${ }^{a}$

\begin{tabular}{|c|c|c|c|c|c|c|c|c|c|c|}
\hline Variable & $P_{i}$ & $T_{i}$ & $P_{p}$ & $T_{p}$ & $P_{m}$ & $T_{m}$ & Ring $_{i}$ & Ring $_{p}$ & Ring $_{m}$ & $\operatorname{Ring}_{m+1}$ \\
\hline Cones & -0.32 & $\begin{array}{c}0.37 \\
(0.09)\end{array}$ & -0.05 & 0.12 & 0.16 & 0.26 & 0.03 & 0.07 & 0.03 & -0.08 \\
\hline Fertile scales & -0.29 & $\begin{array}{l}0.71 \\
(0.001)\end{array}$ & -0.15 & 0.32 & 0.37 & 0.06 & 0.31 & 0.19 & 0.27 & 0.28 \\
\hline Formed seeds & 0.19 & 0.17 & -0.1 & 0.07 & 0.11 & -0.33 & $\begin{array}{c}\text { 0.47 } \\
(\mathbf{0 . 0 3})\end{array}$ & $\begin{array}{c}0.36 \\
(0.09)\end{array}$ & 0.09 & -0.05 \\
\hline Filled seeds & -0.21 & $\begin{array}{c}0.42 \\
(0.05)\end{array}$ & -0.16 & $\begin{array}{c}0.43 \\
(0.04)\end{array}$ & 0.00 & 0.34 & -0.24 & 0.08 & $\begin{array}{c}0.36 \\
(0.08)\end{array}$ & 0.24 \\
\hline Germination velocity & -0.11 & 0.31 & -0.05 & 0.14 & -0.27 & $\begin{array}{c}0.44 \\
(\mathbf{0 . 0 3})\end{array}$ & -0.09 & -0.16 & -0.02 & -0.33 \\
\hline Seed mass & -0.21 & 0.19 & $\begin{array}{r}-0.36 \\
(0.09)\end{array}$ & $\begin{array}{c}0.56 \\
(0.008)\end{array}$ & -0.28 & $\begin{array}{c}0.63 \\
(0.003)\end{array}$ & -0.23 & -0.04 & 0.31 & 0.11 \\
\hline
\end{tabular}

a P: total precipitation from June to August; T: mean temperature between June and August; ring: mean ring index; subscript $i$ : year of cone

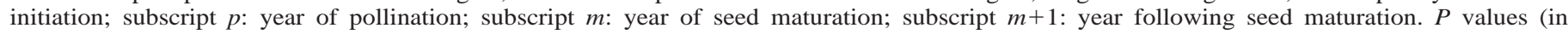
parentheses) given for correlations significant at $P \leq 0.1$; correlations significant at $P<0.05$ shown in boldface.

Sorokina, and Danovich, 1986), and starch (Moore and Nozzolillo, 1991) accumulate in the gametophyte and embryo. Our study shows positive correlations between seed mass and temperature during the seasons of pollination and maturation, suggesting that the resource transfer toward the developing seeds is significant during both of these periods, and that the resources available for seed growth depend on temperature.

However, this seemingly important resource drain to the cones (and the seeds they contain) does not seem to affect growth adversely, because both radial and longitudinal growth are positively correlated with reproductive effort during the period of maximum reproductive investment (Tables 2-4). Indeed, growth and reproduction are influenced by many of the same factors and will both increase when conditions favor carbon gain. In the subarctic, where severe climatic conditions often restrict plant growth, a warm and relatively long growing season could imply a greater overall carbon pool and thus permit increased allocation to all biological functions.

Moreover, the true energy cost of reproduction is often less than would appear based on the relatively high proportion of reproductive biomass. Indeed, young pine cones are green and photosynthetic, and contribute directly to their own energy budget (Linder and Troeng, 1981; Dick, Smith, and Jarvis, 1990). The cones of Pinus serotina fix $19.2 \%$ of the carbon necessary for their production (Bazzaz, Carlson, and Harper, 1979). Furthermore, reproductive structures stimulate the photosynthetic activity of neighboring sources, through either direct sink action or hormonal effects (Wardlaw, 1968, 1990; Weaver and Johnson, 1985). Thus, a higher photosynthetic rate on reproductive branches compensates for the additional sinks, in order to produce equivalent or even higher vegetative biomass relative to sterile branches (e.g., Dick, Jarvis, and Leaky, 1990; Dick, Leaky, and Jarvis, 1990; Thiébaut and Comp, 1991).

In pines, female reproductive buds differentiate from long-shoot buds (Prat, 1951); cone production thus necessarily entails a decrease in the number of lateral buds. However, in the studies by Dick and collaborators (1990) on Pinus contorta, this trade-off was expressed as a drop in the number of latent buds and did not affect the number of lateral shoots formed. Female cones thus did not constitute an important resource drain because their only effect on local vegetative growth occurred at the level of meristem differentiation. In fact, female cone production increased vegetative growth of reproductive shoots, although it diminished the number of latent meristems available for future growth (Dick, Leaky, and Jarvis, 1990). These authors also showed a negative effect of male cones on the vegetative biomass of the developing shoot and main stem. Pollen cones differentiate from short-shoot primordia (Prat, 1951) and thus necessarily entail lower needle production. Yet, in the study by Dick, Jarvis, and Leaky (1990), male strobili also caused a decrease in the number of lateral shoots as well as stem and needle mass, and thus had a considerable impact on local growth, not only through morphological constraints, but also via resource or hormonal depletion.

Our study did not evaluate the annual production of pollen cones, because they do not leave persistent traces. However, male strobilus production is generally well correlated with female cone number (Hyde, 1963; Caron and Powell, 1989b). Moreover, in Pinus contorta, the reduction in local growth due to the presence of male cones is compensated for by an increase in photosynthetic rate such that total carbon assimilation (Dick, Jarvis, and Barton, 1990) and annual stem increment (Dick, 1991) are not affected by either male or female reproduction.

Conclusions-Climatic conditions during the three seasons involved in cone development significantly influence the production of viable seeds in Pinus banksiana at the northern limit of the species range. In general, reproduction is favored by warm summers; this positive relationship might, in part, reflect the effect of relatively long growing seasons, which, in the subarctic, might be necessary for reproductive structures to complete their development before winter. The relationship between reproduction and precipitation is less apparent (the weather data we used were from a more maritime station, and precipitation is spatially very variable), but dry conditions seem to stimulate cone initiation. In the boreal for- 

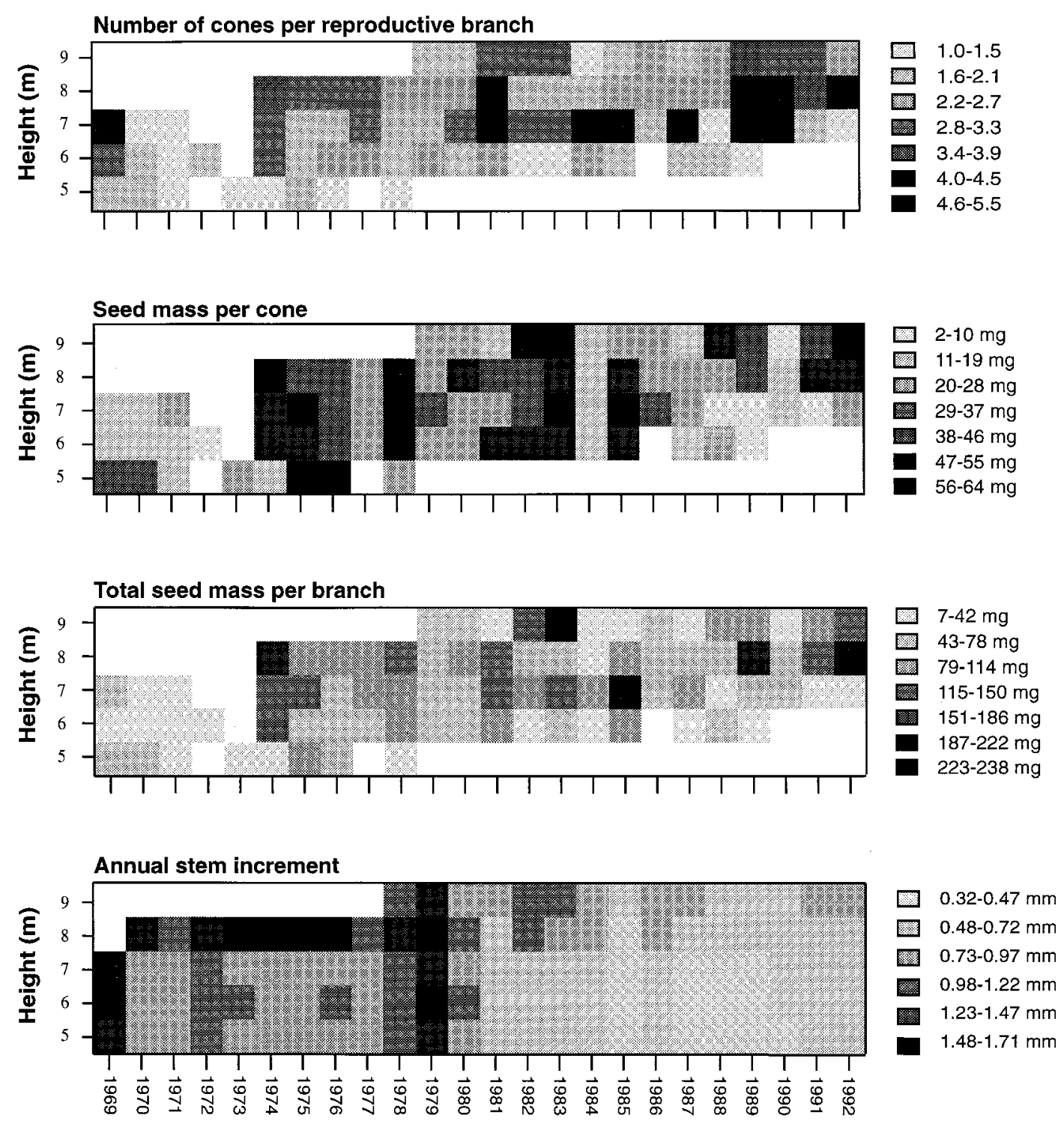

\section{Year}

Fig. 3. Stem analyses showing the number of cones per reproductive branch, seed mass per cone (mg), total seed mass per branch (mg), and annual stem increment $(\mathrm{mm})$, according to year (pollination year for the reproductive variables) and height ( $\mathrm{m}$ ) in the tree crown for an individual from a population of Pinus banksiana at the northern limit of the species' distribution in Québec.

TABLE 3. Results of the partial Mantel tests (and associated $P$ value) between different reproductive variables and stem radial growth during the seasons of cone initiation $\left(\right.$ ring $\left._{i}\right)$, pollination $\left(\right.$ ring $\left._{p}\right)$, and seed maturation $\left(\right.$ ring $_{m}$ ) for Pinus banksiana at the northern limit of its distribution in Québec. ${ }^{\mathrm{a}}$

\begin{tabular}{lccc}
\hline \hline \multicolumn{1}{c}{ Variable } & Ring $_{i}$ & Ring $_{p}$ & Ring $_{m}$ \\
\hline Cones & -0.09 & -0.02 & -0.02 \\
Seed mass per cone & $(0.07)$ & & \\
& -0.08 & 0.03 & $\mathbf{0 . 1 4}$ \\
Total seed mass per branch & $(0.05)$ & & $\mathbf{( 0 . 0 0 7 )}$ \\
& -0.09 & -0.01 & 0.08 \\
\hline
\end{tabular}

${ }^{a} P$ values (in parentheses) shown for tests significant at $P \leq 0.1$; tests significant at $P<0.05$ shown in boldface. est, high cone production and seed viability are often associated with warm and dry summers (Hofgaard, 1993). The same trends appear within the tree: reproductive output is greater in the southern quadrant of the crown, where temperature and solar radiation are higher. Houle and Filion (1993) have examined the interannual variations of seed production of two jack pine populations and have shown similar results: cone yield was favored by warm, dry autumns during bud initiation, seed viability was positively correlated with temperature during the season of fertilization, and seed mass increased with dry conditions during the season of pollination and with high temperatures during seed maturation.

We observed fewer filled and viable seeds per cone than has been reported from more central areas of the 
TABLE 4. Spearman's coefficients of rank correlation $\left(r_{s}\right.$ and associated $P$ value) between different reproductive variables and the local growth (ring: radial growth; elong: terminal elongation) of two individual branches (7S and 8W) from tree 292 for Pinus banksiana at the northern limit of its distribution in Québec. ${ }^{\text {a }}$

\begin{tabular}{|c|c|c|c|c|c|c|}
\hline Branch & $\operatorname{Ring}_{i}$ & $\operatorname{Ring}_{p}$ & Ring $_{m}$ & Elong $_{i}$ & Elong $_{p}$ & Elong $_{m}$ \\
\hline \multicolumn{7}{|l|}{ Branch 7S } \\
\hline Cones & 0.07 & -0.11 & -0.20 & 0.21 & 0.11 & -0.21 \\
\hline Seed mass per cone & 0.34 & $\begin{array}{c}\mathbf{0 . 5 1} \\
(\mathbf{0 . 0 3})\end{array}$ & $\begin{array}{l}\text { 0.70 } \\
(\mathbf{0 . 0 0 5})\end{array}$ & 0.32 & $\begin{array}{c}0.58 \\
(0.09)\end{array}$ & $\begin{array}{c}\text { 0.78 } \\
(\mathbf{0 . 0 3})\end{array}$ \\
\hline Seed mass per branch & $\begin{array}{c}0.44 \\
(0.08)\end{array}$ & 0.34 & 0.30 & 0.57 & $\begin{array}{c}0.67 \\
(0.05)\end{array}$ & $\begin{array}{c}0.71 \\
(0.04)\end{array}$ \\
\hline \multicolumn{7}{|l|}{ Branch 8W } \\
\hline Seed mass per branch & 0.23 & 0.03 & $\begin{array}{c}0.47 \\
(0.06)\end{array}$ & -0.23 & -0.30 & 0.53 \\
\hline
\end{tabular}

${ }^{a}$ Subscripts are defined as follows: $i$ : year of cone initiation; $p$ : year of pollination; $m$ : year of seed maturation. $P$ values (in parentheses) shown for correlations significant at $P \leq 0.1$; correlations significant at $P<0.05$ shown in boldface.

jack pine range (Popovich, Demers, and Gagnon, 1970; Jeffers, 1985). Indeed, low numbers of filled and viable seeds per cone seem characteristic of conifers in the northern part of the boreal forest (O'Reilly and Farmer, 1991; Hofgaard, 1993), and are to be expected if reproductive success depends on high temperatures, a somewhat rare commodity in the subarctic.

Our study does not show that increased investment in reproduction entails a decrease in vegetative growth, even under the stressful conditions of the subarctic. Allen and Platt (1990) have shown that in Nothofagus solandri at low altitude reproductive output oscillated according to regular internal cycles; however, at higher elevations, interannual fluctuations of reproductive effort followed climatic fluctuations. Thus, resource allocation trade-offs may, in fact, be less important in "marginal" environments. In the valley of the Great Whale river, both growth and reproduction of Pinus banksiana are in part limited by climate (especially temperature and length of the growing season). In years with a prolonged growing season, total photosynthesis increases, the global energy budget of the plant is higher, and more resources are available; then, investment in both growth and reproduction increases. A trade-off is not apparent between growth and reproduction because both vary similarly through time, following the fluctuations of climate.

\section{LITERATURE CITED}

Allen, R. B., AND K. H. Platt. 1990. Annual seedfall variation in Nothofagus solandri (Fagaceae), Canterbury, New Zealand. Oikos 57: 199-206.

Bazzaz, F. A., R. W. Carlson, and J. L. Harper. 1979. Contribution to reproductive effort by photosynthesis of flowers and fruits. $\mathrm{Na}$ ture 270: 554-555.

Briffa, K. R., T. S. Bartholin, D. Eckstein, P. D. Jones, W. Karlén, F. H. Schweingruber, AND P. Zetterberg. 1990. A 1,400-year tree-ring record of summer temperatures in Fennoscandia. Nature 346: 434-439.

Brodie, C., G. Houle, AND M.-J. Fortin. 1995. Development of a Populus balsamifera clone in subarctic Québec reconstructed from spatial analyses. Journal of Ecology 83: 309-320.

Cannell, M. G. R. 1985. Dry matter partitioning in tree crops. In M. G. R. Cannell and J. E. Jackson [eds.], Attributes of trees as crop plants, 160-194. Institute of Terrestrial Ecology, Huntingdon, UK.

Caron, G. E., and G. R. Powell. 1989a. Cone size and seed yield in young Picea mariana trees. Canadian Journal of Forest Research 19: 351-358.

$\longrightarrow$, AND $\longrightarrow$. 1989b. Patterns of seed cone and pollen cone production in young Picea mariana trees. Canadian Journal of Forest Research 19: 359-364.

Cody, M. L. 1966. A general theory of clutch size. Evolution 20: 174184.

CoOK, E. R., AND G. C. JACOBY. 1977. Tree-ring-drought relationships in the Hudson Valley, New York. Science 198: 399-401.

CREMER, K. W. 1992. Relations between reproductive growth and vegetative growth of Pinus radiata. Forest Ecology and Management 52: 179-199.

DAUBENMIRE, R. 1960. A seven year study of cone production as related to xylem layers in Pinus ponderosa. American Midland Naturalist 64: 187-193.

Despland, E. 1995. Reproduction et croissance du pin gris à la limite nord de sa répartition: influences climatiques et conflits d'allocation. Master's thesis. Faculté des sciences et de génie, Université Laval, Québec, Canada.

Desponts, M. 1990. Dynamisme récent et holocène du pin gris à sa limite septentrionale de distribution au Nouveau-Québec. Ph.D. dissertation. Faculté des sciences et de génie, Université Laval, Québec, Canada.

- AND S. PAYeTte. 1992. Recent dynamics of jack pine at its northern distribution limit in northern Québec. Canadian Journal of Botany 70: 1157-1167.

Dick, J. M. 1991. Influence of reproductive structures on the morphology and physiology of Pinus contorta trees. Naturalia Monspeliensia, numéro hors série A7: L’Arbre, Biologie et Développement. Actes du Deuxième Colloque International sur l'Arbre, Montpellier, France. September 10-15, 1990.

- P. G. JARVIS, AND C. V. M. BARTON. 1990. Influence of male and female cones on assimilate production of Pinus contorta trees within a forest stand. Tree Physiology 7: 49-63.

- - - AND R. R. B. LEAKY. 1990. Influence of male cones on early season vegetative growth of Pinus contorta trees. Tree Physiology 6: 105-117.

- R. R. B. LEAKY, AND P. G. JARVIS. 1990. Influence of female cones on the vegetative growth of Pinus contorta trees. Tree Physiology 6: 151-163.

, R. SMith, AND P. G. JaRvis. 1990. Respiration rate of male and female cones of Pinus contorta. Trees, Structure and Function 4: 142-149.

Donokaya, L. I., Z. P. Sorokina, and K. N. Danovich. 1986. Dynamics in protein and dry mass content in the cytoplasm of developing female gametophyte cells in Pinus sylvestris. Fiziologiya Rastenii 33: 533-541.

Ebell, L. F. 1967. Cone production induced by drought in potted Douglas fir. Canadian Department of Forestry Bimonthly Research Notes 23: 26-27. 
EKLUND, B. 1954. Variation in the width of the annual rings in pine and spruce due to climatic conditions in northern Sweden during the years 1900-1944. Meddelanden från Statens skogs-forskningsinstitut 47: 1-63.

FrASER, D. A. 1962. Apical and radial growth of white spruce (Picea glauca (Moench) Voss) at Chalk River, Ontario, Canada. Canadian Journal of Botany 40: 659-668.

GAdGIL, M., AND W. H. Bossert. 1970. Life historical consequences of natural selection. American Naturalist 104: 1-24.

Gross, H. L. 1972. Crown deterioration and reduced growth associated with excessive seed production by birch. Canadian Journal of Botany 50: 2431-2437.

Gysel, L. W. 1971. A ten-year analysis of beechnut production and use in Michigan. Journal of Wildlife Management 35: 516-519.

HofGAARD, A. 1993. Seed rain quantity and quality, 1984-1992, in a high altitude old-growth spruce forest, northern Sweden. New Phytologist 125: 635-640.

Houle, G., AND L. Filion. 1993. Interannual variations in the seed production of Pinus banksiana at the limit of the species distribution in Northern Québec, Canada. American Journal of Botany 80: $1242-1250$.

Hyde, H. A. 1963. Pollen fall as a means of seed prediction in certain trees. Grana Palynologica 4: 217-230.

JEFFERS, R. M. 1985. Seed quality in five Jack pine stands in north central Wisconsin. USDA, Forest Service, Research Note NC-328.

Johnson, M. A., J. A. Carlson, J. H. Conkey, And T. L. Noland. 1987. Biochemical changes associated with zygotic pine embryo development. Journal of Experimental Botany 38: 518-524.

Kelly, D. 1994. The evolutionary ecology of mast seeding. Trends in Ecology and Evolution 9: 465-470.

Kleinschmidt, J., J. Schmidt, AND B. Hosenfeld. 1980. Induction of flowering in Norway spruce and Douglas fir. Forst-und-Holzwirtschaft 35: 240-242.

LEE, K. J. 1979. Factors affecting cone initiation in pines: a review. Institute of Forest Genetics Research Report 15. Suwan, Korea.

LEGENDRE, P., AND M.-J. ForTin. 1989. Spatial pattern and ecological analysis. Vegetatio 80: 107-138.

- , AND A. VAudor. 1991. Le Progiciel R-analyse multidimensionnelle, analyse spatiale. Versions CMS (IBM), VMS (VAX) et Macintosh. Université de Montréal, Québec, Canada.

LESTER, D. T. 1967. Variation in cone production of red pine in relation to weather. Canadian Journal of Botany 45: 1683-1691.

Linder, S., And E. Troeng. 1981. The seasonal course of respiration and photosynthesis in strobili of Scots pine. Forest Science 27: 267-276.

LinHART, Y. B., AND J. B. MitTON. 1985. Relationships among reproduction, growth rates, and protein heterozygosity in Ponderosa pine. American Journal of Botany 72: 181-184.

LowRy, W. P. 1966. Apparent meteorological requirements for abundant cone crop in Douglas fir. Forest Science 12: 185-192.

Maguire, W. P. 1956. Are Ponderosa pine cone crops predictable? Journal of Forestry 54: 778-779.

Moore, M. I., AND C. Nozzolillo. 1991. Illustrated guide to stages of jack pine cone development. COFRDA Report 3313. Forestry Canada, Ontario region, Sault-Ste-Marie, Canada.

MorRIS, R. F. 1951. The effects of flowering on the foliage production and growth of balsam fir. Forestry Chronicle 27: 40-57.

Mugnisjah, W. Q., AND S. NAKAmura. 1986. Stress for seed vigour evaluation in soybean. Seed Science and Technology 14: 95-103.

NiENSTAEDT, H. 1985. Inheritance and correlation of frost injury, growth, flowering and cone characteristics in White spruce, Picea glauca (Moench) Voss. Canadian Journal of Forest Research 15: 498-504.

O'ReIlly, G. J., AND R. E. FARMer. 1991. Phenotypic variation in cone and seed characteristics of tamarack in north-western Ontario. Tree Planter's Notes (Summer 1991): 18-22.

Ovington, J. D. 1961. Some aspects of energy flow in plantations of Pinus sylvestris L. Annals of Botany 25: 12-20.

. 1963. Flower and seed production: a source of error in estimating woodland production energy flow and mineral cycling. $\mathrm{Oi}$ kos 14: 148-153.

Owens, J. N. 1991. Flowering and seed set. In A. S. Raghavendra [ed.], Physiology of trees, 247-273. John Wiley \& Sons, New York, NY.
, AND M. D. Blake. 1986. Production de Semences Forestières. Rapport d'information PI-X-53F du Service Canadien des Forêts. Institut forestier national de Petawawa, Canada.

- - A. M. Colangeli, And S. J. Morris. 1991. Factors affecting seed set in Douglas fir (Pseudotsuga menziesii). Canadian Journal of Botany 69: 229-238.

- AND M. Molder. 1979. Sexual reproduction in Western red cedar (Thuja plicata). Canadian Journal of Botany 58: 1376-1393.

, S. J. Simpson, AND M. Molder. 1981. Sexual reproduction of Pinus contorta. I Pollen development, the pollination mechanism, and early ovule development. Canadian Journal of Botany 59: $1828-1843$.

, - AND -1 1982. Sexual reproduction of Pinus contorta. II Postdormancy ovule, embryo and seed development. Canadian Journal of Botany 60: 2071-2083.

OYAMA, K. 1990. Variation in growth and reproduction in the neotropical dioecious palm Chamaedorea tepejilote. Journal of Ecology 78: 648-663.

Popovich, S., A. Demers, And J. D. Gagnon. 1970. Production en cônes et semences d'un peuplement de pin gris de 65 ans de la région boréale du Québec. Naturaliste Canadien 97: 553-558.

PRAT, H. 1951. Histophysiological gradients and plant organogenesis (Part II). Botanical Review 17: 693-746.

Rehfeld, G. E., A. R. Stage, and R. T. Bingham. 1971. Strobili development in Western White Pine: periodicity, prediction and association with weather. Forest Science 17: 454-461.

RoE, E. I. 1963. Seed stored in cones of some jack pine stands, northern Minnesota. USDA Forest Service, Research Paper LS-1.

RoHMEDER, E. 1967. Beziehungen zwischen Frucht-bzw Samenerzeugung und Holzerzeugung der Waldbäume. Allgemeine Forstzeitschrift 22: 33-39.

Rousseau, C. 1974. Géographie floristique du Québec/Labrador. Les Presses de 1'Université Laval, Sainte-Foy.

Rudolph, T. D., And P. R. Laidly. 1990. Jack pine. In R. M. Burns and B. H. Honkala [eds.], Silvics of North America, vol. 1, Conifers, 280-293. USDA Forest Service, Agriculture Handbook 654. Washington, DC.

SCHANTZ-HANSEN, T. 1941. A study of jack pine seed. Journal of Forestry 39: 980-990.

SHOULDERS, E. 1973. Rainfall influences female flowering in slash pine. USDA Forest Service, Research Paper SO-150.

Silvertown, J. W. 1980. The evolutionary ecology of mast seeding in trees. Biological Journal of the Linnean Society 14: 235-250.

Simpson, J. D., And G. R. Powell. 1981. Some factors influencing cone production on young black spruce in New Brunswick. Forestry Chronicle 57: 267-269.

SingH, H. 1978. Embryology of gymnosperms. Gebrüder Borntraeger, Berlin.

SokAl, R. R., AND F. J. RohlF. 1981. Biometry, 2d. ed. W.H. Freeman, San Francisco, CA.

SteARns, S. 1976. Life history tactics: a review of the ideas. Quarterly Review of Biology 51: 3-47.

. 1989. Trade-offs in life history evolution. Functional Ecology 3: 259-268.

Tautorus, T. E., L. C. Fowke, And D. I. Dunstan. 1991. Somatic embryogenesis in conifers. Canadian Journal of Botany 69: 18731899.

ThiÉBAut, B., AND B. COMP. 1991. Répartition de la matière sèche entre les organes végétatifs et reproducteurs dans les pousses annuelles du hêtre européen (Fagus sylvatica). Canadian Journal of Botany 69: 2225-2231.

van Vredenburch, C. L. H., and J. G. A. La Bastide. 1969. The influence of meteorological factors on the cone crop of Douglas fir in the Netherlands. Silvae Genetica 18: 182-186.

WARDLAW, I. F. 1968. The control and pattern of movement of carbohydrates in plants. Botanical Review 34: 79-105.

. 1990. The control of carbon partitioning in plants. New Phytologist 116: 341-381.

WEAVER, R. J., AND J. O. JohnSON. 1985. Relation of hormones to nutrient mobilisation and the internal environment of the plant: the supply of mineral nutrients and photosynthate. In R. P. Pharis and D. M. Reid [eds.], Hormonal regulation of development. III. Role 
of environmental factors, 3-36. Encyclopaedia of plant physiology, New Series, vol. 11. Springer-Verlag, New York, NY.

West, M. M., And J. N. A. LotT. 1993. Studies of mature seeds of eleven Pinus species differing in seed weight. I. Element concentrations in embryos and female gametophytes. Canadian Journal of Botany 71: 570-576.

Willson, M. F. 1986. On the costs of reproduction in plants: Acer negundo. American Midland Naturalist 115: 204-207.

Wilson, C. V. 1971. Le climat du Québec. Atlas climatique, première partie. Service météorologique canadien, Ottawa, Canada.
Woodward, A., D. G. Silsbee, E. G. Schreiner, and J. E. Means. 1994. Influence of climate on radial growth and cone production in subalpine fir (Abies lasiocarpa) and mountain hemlock (Tsuga mertensiana). Canadian Journal of Forest Research 24: 11331143.

Yanagihara, T., K. TochiaKi, and K. Arai. 1960. On the relation between the harvest of Japanese larch seed and meteorological conditions. Journal of the Japanese Forest Society 42: 347-351.

YounG, J. A., AND C. G. Young. 1992. Seeds of woody plants in North America. Dioscorides Press, Portland, OR. 